\title{
COOPERATIVE PRINCIPLES IN PRACTICE: EXPERIENCES OF SERBIA ${ }^{1}$
}

\author{
Marija Nikolić2, Ivan Božić̉
}

\begin{abstract}
Cooperative principles represent one of the three elements of cooperative identity. In their current form, they have existed since 1995, when they were adopted by the International Cooperative Alliance, and they represent a recommendation to cooperatives around the world on how to organize their business. Adherence to these recommendations in everyday business practice of cooperatives is extremely challenging. In fact, there is a consensus in the literature that deviation from cooperative principles is inevitable. The paper analyzes the experiences of the Republic of Serbia in the implementation of cooperative principles from time of the first cooperatives until today, with special emphasis on agricultural cooperatives. The aim of this paper is to examine the extent to which cooperative principles are respected in the business of cooperatives in Serbia, what factors led to deviations from these recommendations and what consequences this had on the success of these organizations. The paper presents a synergy of theoretical consideration of the problem and examination of experiences of agricultural cooperatives in Serbia in the implementation of cooperative principles. Conducted research indicate that during the development of cooperatives, different levels of deviations from cooperative principles in the practice of agricultural cooperatives were recorded, from very mild to extremely significant deviations that led to the suppression of true cooperative nature. Modern cooperative practice in Serbia is marked by a
\end{abstract}

1 The authors are grateful to the Ministry of Education, Science and Technological Development of the Republic of Serbia for financial support based on the Contract on the implementation and financing of scientific and research work in 2021 between Faculty of Agriculture, University of Belgrade and Ministry of Education, Science and Technological Development of the Republic of Serbia, no. 451-03-9/2021-14/200116.

2 Marija Nikolić, Ph.D., Assistant Professor, Faculty of Agriculture, University of Belgrade, Nemanjina Street no. 6, 11080 Zemun, Serbia, Phone: +381 1144134 03, E-mail: mnikolic@agrif.bg.ac.rs

3 Ivan Božić, M.Sc., M.Econ., LuxPayroll S.a.r.l., 15 Rue de Industrie, L-8069 Luxembourg, Phone: +352 287734 50, E-mail: ivan.s.bozic@gmail.com

4 Dragica Božić, Ph.D., Full Professor, Faculty of Agriculture, University of Belgrade, Nemanjina Street no. 6, 11080 Zemun, Serbia, Phone: +381 1144134 93, E-mail: bozdrag@agrif.bg.ac.rs 
low level of knowledge of the elements of cooperative identity by the members and management of cooperatives, which further stipulates the posibility of their implementation in practice.

Key words: agricultural cooperatives, Serbia, cooperative principles, implementation.

JEL $^{5}$ : Q13, P1

\section{Introduction}

One of the common issues analyzed in the cooperative literature is the specifics of cooperatives. In order to point out that cooperatives have advantages over other legal entities, it is necessary to show that they have certain specifics. Cooperative principles are the cornerstones of the evaluation of the validity of a cooperative and they can prove whether a cooperative is genuine one or not (Szabó, 2009). Even more, they provide a guiding light in times of social, political and economic crises (Benson et al., 2017; Zakić, Nikolić, 2018).

Cooperatives may take many forms, but most of them follow the same seven cooperative principles adopted by the International Co-operative Alliance (ICA) in 1995. Although ICA is internationally recognized as the most important organization for all types of cooperatives, it only has advisory role. This implies that cooperatives are not legally constrained to apply ICA co-op principles. In some countries cooperative principles are included in laws governing cooperatives, meaning that their implementation is obligatory. However, there are many proves that cooperatives do not implement cooperative principles in everyday practice. Why is that so? What are the reasons and consequences of such actions? Cooperative literature can provide answers to these questions.

In order to talk about the implementation of cooperative principles in practice, it is necessary that members and management of cooperatives know the elements of the identity of cooperatives, especially the principles themselves. The lack of cooperative education resulted in a low level of knowledge in many countries, which is confirmed in the cooperative literature. Zeuli and Radel (2005) believe that knowledge and understanding of cooperative principles varies from co-op to coop, especially in different types of cooperatives. Milton and Klostes (2009) claim that this general phenomenon of cooperative illiteracy is not limited to the rural population, but that the situation is similar among the experts in the field, which is especially devastating. With the intensification of cooperative education since 2010 (ICA, 2011), and especially within the celebration of 2012 as the UN International Year of Cooperatives, numerous activities aimed at increasing awareness and knowledge of cooperative values and principles have been implemented.

5 Article info: Review Article, Received: $13^{\text {th }}$ June 2021, Accepted: $21^{\text {st }}$ July 2021. 
Principles are in the centre of cooperatives, they are the bones of cooperatives work (Benson et al., 2017). However, many authors advocate the attitude that it is almost impossible to implement them fully into everyday practice. McNamara (2007) believes that respect of cooperative principles not only helps preserving the cooperative identity, but also provides certain comparative advantages. Szabó (2009) disagrees and claims that it is not certain that cooperatives that follow principles will be viable ones and can survive in the rapidly changing environment. He further claims ,that co-operative principles are sometimes obstacles from the point of flexible business activity". According to Dunn (1988), deviations of cooperative principles are inevitable in practice. Nilsson (1996) agrees and adds that respect of cooperative principles in practice is more probation. Some authors even believe that cooperatives are free to change principle as needed or to form its own set of principles, because there are no legal requirements for cooperatives to obey the ICA co-op principles (Novkovic, 2008; Szabó, 2009).

There are similar standpoints in domestic cooperative literature. Analyzing cooperative practice in Serbia in the transition period, Bateman and Pennarz (2009) point out that many agricultural cooperatives abandon cooperative principles, which can be concluded based on the growing gap between the number of full and associated members. Some authors make a gradation in the importance of applying certain principles. Babović et al. (2009) emphasize that if the principle of economic motivation is not met, the cooperative cannot continue to operate. Other authors think that it is important that the principles are respected as a whole. Nikolić (2018) believes that avoiding the principles might results in losing the cooperatives identity. Markovic (2007) claims that there are deviations in domestic cooperative practice, especially from the open membership and democratic member control, and conclude that the key problem is the non-existence of cooperatives that operate in accordance with international cooperative principles. Njegovan (2011) has similar views, stating that in the period after the Second World War (WWII), none of the cooperatives in Serbia was based on cooperative principles.

The paper analyzes the extent to which cooperative principles are respected in agricultural cooperatives in Serbia. Starting from this goal, three periods in the domestic cooperative history have been identified: first, from the time of the creation of cooperatives to the WWII; second, from the end of the WWII until the 2000s, and third, which refers to the business of cooperatives in today's conditions. The implementation of the principles in the first two stages was examined based on a review of the available literature, while the implementation of the principles in modern conditions was assessed based on conducted field research. After presentation of the research results and their discussion, conclusions were formed. 


\section{Material and Methods}

The research presented in this paper can be divided into two parts. The desk research method and secondary data have been used for analysing the compliance with cooperative principles in agricultural cooperatives from their foundation until today. The historical method and the method of analysis and synthesis have been used to examine to what extent the cooperative principles were respected, which principles were most often deviated from, and whether this had consequences for the cooperative sector as a whole.

The second part of the paper emphasizes the knowledge and implementation of cooperative principles in agricultural cooperatives in modern conditions. The results presented in this part of the paper were obtained by field research and interpretation of the obtained data. The survey covered a total of 108 agricultural cooperatives, or $14.6 \%$ of the total number of registered agricultural cooperatives in that time, according to the data of the Serbian Business Register Agency. In each cooperative, a face-to-face survey of the director and one of the cooperative members was conducted. The paper presents only indicators obtained by applying descriptive statistics. Data processing was performed in the SPSS program.

\section{Results and Discussions}

Agricultural cooperatives in Serbia have a long tradition, as is often pointed out in domestic literature. Depending on the subject of analysis, the development of cooperatives can be divided into several phases. From the aspect of implementation of cooperative principles, the development of cooperatives, in the opinion of the author, should be divided into three phases, as shown in the next part of the paper.

\section{Implementation of cooperative principles in agricultural cooperatives from the formation of first cooperatives to the Second World War}

The emergence of the first cooperatives in Serbia takes place almost simultaneously with the emergence of the first such organizations in the world. This implies that the business experience of these organizations was scarce, i.e. that the members of the cooperatives were able to independently define the rules that were followed in business. The first cooperatives formed on the territory of today's Serbia were founded in urban areas, and many of them did not have a pure cooperative structure (Kišgeci, Vitez, 1994). However, the first cooperatives formed in rural areas defined cooperative values and principles following the example of early European cooperative practice, especially the credit agricultural cooperatives under Raiffeisen model. At the same time, in the creating of the business rules of cooperatives, 
significant attention was paid to their economic survival and the characteristics of cooperative members (Nikolić, 2014).

In these early stages of the formation of cooperative organizations, there were no internationally recognized cooperative principles, but the rules that cooperatives included in their founding acts and regulations were respected. Since these were young organizations, the business rules defined in this way have been strictly implemented in practice. Avramović (1897) states that agricultural cooperatives "have their own principles according to which they must be managed and which must be kept in their entirety".

Lack of business experience is certainly one of the main reasons for the strict implementation of the cooperative principles of that time. In addition, the membership structure was such that it was necessary to define firm rules of conduct, which relied heavily on the ethical values and characteristics of the cooperative members. Membership in cooperatives was twofold, especially in terms of educational structure. Nikolić (2014) states that the leading members in agricultural cooperatives in Serbia at the end of the $19^{\text {th }}$ and the beginning of the $20^{\text {th }}$ century were respectable and educated people, such as teachers, priests and leading members of local communities. They led other, less educated co-op members and set moral standards that were respected. Insisting on these characteristics of cooperative members led to respect for cooperative values and consequently cooperative principles.

With the establishment of a larger number of cooperatives and their popularization, the Central Union of Serbian Agricultural Cooperatives (Glavni savez srpskih zemljoradnickih zadruga) provided a more active role and assistance in founding new cooperatives. This union published draft rules of credit, purchasing, grain, livestock and other types of cooperatives in its newspaper "Agricultural co-operative" (Zemljoradnička zadruga). These rules were very strict and unified for all types of cooperatives, and cooperatives had very little freedom to change them. Special emphasis was placed on the open membership principle, but only for those persons who possess the required character traits (Kostov, 2006).

The first period in the development of cooperatives in Serbia, therefore, is characterized by the existence of business rules of cooperatives that were later transformed in cooperative principles. Due to limited experience, membership structure, and later as a consequence of the activities of cooperative unions, cooperatives strictly adhered to cooperative principles in their business operations. With the consistent implementation of cooperative rules, cooperatives developed successfully until the beginning of the WWII. 


\section{Deviations of cooperative principles in agricultural cooperatives in the period after the Second World War}

The period from the end of the WWII to the transition years abounds in different approaches to cooperative movement on the territory of the Republic of Serbia, most of which were closely connected with the political and social circumstances in the country. These misconceptions of cooperatives have resulted not only in disrespect for cooperative principles, but also in significant deviations from the true nature of cooperatives.

One of the first "experiments" was the creation of peasant labour cooperatives formed based on the model of the Soviet "kolhoz", so-called collective farms (Ranđelović, 1994). Apart from the name, these organizations had little contact with real cooperatives. Mihajlović and Tomić (1992) characterize these organizations as "entities connected with state authorities, with few elements of a typical cooperative organization and business principles".

The second period that also led to a departure from the true cooperative nature is the period of the so-called self-governing system in which agricultural cooperatives are forced to join agricultural combines. In that way, they lost not only their independence, but also their legal status, which clearly speaks about the state of cooperative organizations. Zakić (2000) believes that the post-war period is characterized by three factors: (1) the cooperative is equated with other social enterprises, (2) cooperative principles are deformed in practice and (3) the process of forming a cooperative is set inversely - from top to bottom.

Although it is illusory to speak of the implementation of cooperative principles in such conditions, it can be emphasized that the principle of voluntary and open membership was most often violated either by forced membership or by making membership conditional on the political suitability of potential members. Another principle that was often violated is the democratic member control, which is characterized by the growing influence of cooperative employees in the decision-making process, which equates the cooperative with state-owned enterprise. Considering the high influence of socio-political factors on the business of the cooperatives, it can also be concluded that the principle of autonomy and independence was significantly neglected. The adjustment of the cooperative principles to the political ideology resulted in the distance from the European and world cooperative movement, which was not characteristic only for Serbia, but for all the countries of the Eastern bloc.

Before the start of the transition processes, new laws that announced a return to internationally recognized cooperative practice were enacted. However, in the early 2000s, a number of organizations appeared that used the term cooperatives 
in their names, but were actually private companies in terms of the way they were organized and operated. In these organizations, the membership consisted of persons connected by family ties, the principle of open membership was not respected, and decision-making was in the hands of a small number, or even one person, most often the director of such so-called cooperatives. All that resulted in significant deviations from the ICA elements of the cooperative identity, adopted in 1995. From the aspect of implementation of cooperative principles, the situation was not significantly better in a number of true cooperatives that were operating at that time. Few studies have confirmed that representatives of the cooperative sector have little knowledge of cooperative principles (IPN, 2010; DAES, 2012), which not only indicates a lack of cooperative education, but also makes it difficult to operate in accordance with these rules.

\section{Knowledge and respect for cooperative principles in agricultural cooperatives in Serbia in modern conditions}

In the post-war development of the cooperative sector in Serbia, significant deviations were noted not only from cooperative principles, but also from international cooperative practice. The adoption of cooperative legislation and the emergence of a larger number of newly formed cooperatives in the first decades of the twentieth century created the possibility of a return to the true cooperative nature. In such conditions, it becomes justified to examine, again, the extent to which cooperative principles are applied in the business of these organizations.

Unlike the European practice, the support for cooperatives in Serbia was until recently exclusively declarative. The first concrete support measures have been recorded in 2017, when the Government of the Republic of Serbia adopted the project "Five Hundred Cooperatives in Five Hundred Villages". One of the key effects of this program is a multiple increase in the number of newly formed cooperatives on an annual basis compared to the previous period (Zakić, Nikolić, 2018). ${ }^{6}$ The newly formed cooperatives have endorsed new members. However, as the co-op education among the rural population is almost non-existent, it is justified to question the extent to which the members of these cooperatives, and their management, are familiar with the cooperative principles.

The results of previously conducted research show very unfavourable trends. In 2009 organisation "Budi svoj covek" conducted a survey which showed that threequarters of cooperative directors never attended any additional training programs.

6 During 2017, 170 new cooperatives were established, and in 2018 (until August), close to 100 new cooperatives were established. For the sake of comparison, in the previous period, only about thirty new cooperatives were established anually: 31 in 2015 and 34 in 2016 (Zakić, Nikolić, 2018). 
According to the IPN ${ }^{7}$ survey (2010), more than half of the directors of agricultural cooperatives in Serbia (53.3\%) do not know the cooperative principles, even at the level of recognition. Of the directors who stated that they know the cooperative principles, $69.9 \%$ recognized all seven. A survey conducted by DAES (2012) gave almost identical results: $54.4 \%$ of directors and $59.5 \%$ of cooperative members in agricultural cooperatives in Serbia did not know the cooperative principles. So, it is justified to be concerned about the possibility of implementing the principles in the practice of agricultural cooperatives.

In the following part of the paper are presents the results of a survey of directors and members of 108 agricultural cooperatives in Serbia.

The lack of cooperative training and education was reflected not only in the ignorance of the elements of the identity of the cooperative, but also in the perception of the importance of organizing into cooperatives. Only half of the respondents $(51 \%$ of directors and $46 \%$ of co-op members) believe that cooperatives represent a better way of organizing farmers comparing to other forms of organizations, while about a third of them do not know that there are any differences between them at all.

Regarding the implementation of the first cooperative principle, voluntary and open membership, almost $90 \%$ of agricultural cooperatives in Serbia respect this rule. Compared to other studies, this is very good result. Iliopoulos and Cook (2004) state that $75.6 \%$ of agricultural cooperatives in the United States practise open membership, while according to Novkovic (2005) this percentage is slightly higher in Canada (85\%). However, it is necessary to emphasize that a significant number of cooperatives in Serbia have a large number of associated members (more than 100) over a long period of time, which is contrary to European cooperative practice. Namely, the status of associated member usually lasts for a shorter period of time in which the potential member should decide whether it is in accordance with his wishes and needs to become a full member of the cooperative. If cooperatives in Serbia respect the open membership policy, why the associated member did not become full members? Another possibility is that the associated members are not fully satisfied with the services of the cooperative so they don't want to become full members. As the shares in cooperatives are relatively low, and there are rarely additional requirements that newly admitted members would have to meet, one can question how agricultural cooperatives in Serbia are truely open. Similar findings can be made by reviewing the cooperative literature. Bateman and Pennarz (2009) believe that almost $30 \%$ of cooperatives are not ready to give associated members the opportunity to become full members. Markovic (2007) points out

7 IPN-Institut za primenu nauke u poljoprivredi (Institute for the application of science in agriculture). 
that cooperatives formed by members of several families and cooperatives with significant assets are often closed.

Democratic member control is the cooperative principle that is most applied in practice. Out of 108 cooperative members, only two $(1.8 \%)$ believe that they cannot get involved in decision-making in their cooperative if they want to, while almost three quarters $(73 \%)$ of cooperative members actively participate in decision-making in their cooperative. At the same time, the rule "one member-one vote" is absolutely mandatory in Serbian cooperatives, which is the case in only ten other EU member states, while the others apply the so-called proportional voting (Bijman et al., 2012).

The third cooperative principle refers to the economic participation of members in the work of cooperatives, and is manifested by the participation of cooperative members in the formation of capital and distribution of surplus. The implementation of this principle allows relatively little freedom, since these elements of cooperative business are usually regulated by law.

The research showed that more than half of the respondents (54\%) believe that the shares in cooperative capital should be equal. However, the Article 20 of the new Law on Cooperatives (2015) stipulates that a cooperative member may have only one share in the cooperative, but also that they do not have to be equal, while the minimum level of share is determined by cooperative rules.

The secondary interpretation of the third principle concerns the distribution of surplus. The Article 59 of the Law on Cooperatives (2015) stipulates that a cooperative member may participate in the distribution of surplus in proportion to the size of his share and the value of the turnover through the cooperative, which is regulated in more detail by cooperative rules. Although this is not entirely contradictory to the cooperative nature, the distribution of profits according to the amount of capital invested is characteristic of capital oriented companies, not companies of persons, such as cooperatives. It is positive, of course, that the cooperative members themselves have the opportunity to make a final decision on the criteria by which the distribution of surplus will be carried out. On the other hand, this further indicates the need for decision-makers in cooperatives to be familiar with the specifics of cooperatives, embodied in cooperative principles.

According to a significant part of the respondents (78\%), there are no obstacles to the implementation of the principle of autonomy and independence, i.e. other organizations do not endanger the independence of cooperatives. About a fifth of cooperative directors $(21 \%)$ believe that there are certain influences from financial institutions, such as commercial banks on the work of cooperatives. However, this type of influence also exists on other organizations that apply for 
loans. Considering this, it is only important to ensure fair and equal conditions for all, i.e. to eliminate the influence of the legal status of the person submitting fot the loan on obtaining financial resources.

The fifth principle combines education, training and information. Although it is poorly recognized by cooperative representatives as a principle, it is applied in a relatively large number of cooperatives. Namely, $68 \%$ of directors and $61 \%$ of employees believe that the cooperative invests in their education. The internal communication, i.e. informing employees and members about the work and business results, is implemented in almost $90 \%$ of cooperatives, most often at annual assembly. Informing and educating the external public is significantly less present. There are two aspects of communications and education of local inhabitants. First, agricultural cooperatives most often operate in a limited rural area, which means that the local public is, to some extent, familiar with their work. However, the fifth cooperative principle also implies the education of members of the local community in order to spread the cooperative idea, especially among the younger population, which is almost non-existent in domestic cooperative practice.

The cooperation among cooperatives is a principle aimed at strengthening the potential of cooperatives, which can more effectively meet the needs of membership by working together. A significant role in the implementation of this principle is played by cooperative unions or other cooperative organizations that connect cooperatives, enabling them to enter into joint business activities. Although there are no obstacles to the implementation of this principle, and a significant majority of surveyed directors $(86.2 \%)$ state that their organisation cooperates with at least one other cooperative, the effects of such activities are absent. Therefore, although the principle of cooperation among cooperatives is present, the scope of cooperation is modest, i.e. it does not create positive effects although this is the reason why this rule is included in the cooperative principles in the first place.

The implementation of the youngest cooperative principle - concern for the community, is limited by the amount of surplus of agricultural cooperatives. Despite the limited available resources, about $70 \%$ of directors and members of cooperatives stated that their cooperative helps sports and / or cultural events in the local community. The effects of such activities are certainly positive from the aspect of promoting cooperatives, and to a small extent they affect the quality of life of the local population.

The revitalization of the cooperative sector in Serbia in the post-war period was challenging and faced with numerous difficulties. In such conditions, it becomes even more demanding that cooperative principles are implemented in everyday business. 
The research indicates that there is a lot of space for improvement regarding the level of knowledge of cooperative principles and their implementation, especially to the extent that would result in positive effects on the business of cooperatives.

\section{Conclusions}

Cooperative principles are rules of business, based on positive human qualities, which enable cooperatives to be different from other economic entities. If applied in everyday business, they enable cooperatives not only to preserve their identity, but also to achieve comparative advantages and be more successfully in achieving the goal - meeting the needs of members. The implementation of the principles in practice is faced with numerous challenges, especially in markets with fierce competition, where survival imposes different business rules.

Cooperatives in Serbia have a long tradition during which they went through various phases. From the aspect of implementation of cooperative principles in practice, three phases have been singled out. In the first phase, from the creation of the first cooperatives in Serbia until the Second World War, the cooperatives learned through practice and limited European experience how to conduct business. The rules were defined by the cooperatives themselves and were strictly applied in practice, first on the initiative of prominent people, members of the cooperative, and later with the support of the Central Union of Serbian Agricultural Cooperatives.

The second period, from the Second World War to the beginning of the transition processes, was marked by various experimental phases in the development of cooperatives, which represented a departure from European cooperative practice on various grounds. Not only cooperative principles have not been respected in everyday business, but the term "cooperative" was associated with various noncooperative organizations.

The beginning of transition processes, and especially the period after 2000, represents the third phase. Although significantly neglected and without the state support, that cooperatives usually need during the greatest crises, cooperatives in Serbia have begun to recover. One segment of this process is a return to internationally recognized cooperative principles. The establishment of a number of new cooperatives further encourages hope for the revitalization of this sector. However, from the aspect of implementation of the principles, there is also cause for concern. Representatives of the cooperative sector in Serbia have little knowledge of cooperative values and principles, which is certainly an obstacle in their implementation. Cooperatives are economically weakened and mostly isolated, which imposes the need to fight for survival, and then the implementation of the principles is extremely difficult. 
Nevertheless, the research shows that, in the opinion of the directors and members of agricultural cooperatives, these organizations make efforts to operate in accordance with the principles.

In order for cooperatives to base their business to a greater extent on the elements of cooperative identity, including cooperative principles, a synergistic action of a larger number of institutions is needed, in addition to the cooperatives themselves. More active participation of cooperative unions, following the example of the early stages of cooperative development, would certainly be of great importance, especially in terms of support and education. Educational institutions, such as agricultural faculties and other organizations aimed at supporting the social economy, could contribute in educating members and management of cooperatives, but also the general population, about the specifics of these organizations. Raising the awareness about cooperatives would result in more intensive implementation of cooperative principles in their business.

\section{References}

1. Avramović, M. (1897). Učitelj i zemljoradničke zadruge. Ministarstvo narodne privrede Kraljevine Srbije, Beograd, Srbija.

2. Benson, A., Carabini, C., Brander, E., Romenteau, A. (2017). Good practices in international cooperative development: Why creating knowledge sharing culture is key for international cooperative development work. Cooperatives Europe, Brussels, Belgium, retrieved at: https://coopseurope.coop/sites/default/files/ REPORT CEDP Good\%20pracrices\%20in\%20intl\%20development.pdf, $17^{\text {th }}$ March 2021.

3. Bijman, J., Iliopoulos, C., Poppe, K., Gijselinckx, C., Hagedorn, K., Hanish, M., Hendrikse, G., Kuhl, R., Ollila, P., Pyykkonen, P., van der Sangen, G. (2012). Support for Farmers' Co-operatives: Final report. European Commission, Brussels, Belgium.

4. Babović, M., Bogdanov, N., Stojanović, Ž., Doklestić, S. (2009). Analiza sistema podrške zadrugama u području Stare planine: naučene lekcije. Interni document, UNDP, Beograd, Srbija.

5. Bateman, M., Pennarz, J. (2009). Socijalna preduzeća u Srbiji: institucionalni okvir i praktična iskustva zadruga. UNDP, Beograd, Srbija.

6. Budi svoj čovek (2009). Izveštaj o sprovedenoj analizi zadruga koje učestvuju u agrobiznis obukama. Budi svoj čovek, Beograd, Srbija.

7. DAES (2012). Strategija razvoja zemljoradničkog zadrugarstva u Republici Srbiji. Društvo agrarnih ekonomista Srbije (DAES), Beograd, Srbija. 
8. Dunn, J. R. (1988). Basic Cooperative Principles and Their Relationship to Selected Practices. Journal of Agricultural Cooperation, National Council of Farmer Cooperatives. 3:1-11, doi: 10.22004/ag.econ.46212.

9. ICA (2011). Annual report. International Co-operative Alliance (ICA), Geneva, Switzerland.

10. Iliopoulos, C., Cook, M. (2004). The Organizational, Financial and Ownership Characteristics of US Agricultural Cooperatives: Survey Results From a New Institutional Economics Perspective. In: XV International Cooperatives Forum, Münster, Germany, pp. 301-324.

11. IPN (2010). Zemljoradničke zadruge u Republici Srbiji: Analiza stanja. Institut za primenu nauke u poljoprivredi (IPN), Beograd, Srbija.

12. Kišgeci, J., Vitez, M. (1994). Društveno-ekonomski uslovi nastanka $i$ karakteristike prvih zadruga u Vojvodini: Zadruge Srba i Slovaka. In: 100 godina zemljoradničkog zadrugarstva Srbije, Zadružni savez Srbije, Beograd, Srbija, pp. 19-27.

13. Kostov, R. (2006). 100 godina zemljoradničke zadruge Šimanovci 1905-2005. Zemljoradnička zadruga Šimanovci, Šimanovci, Srbija.

14. Law on cooperatives, Official Gazette of the Republic of Serbia, no. 112/15.

15. Marković, K. (2007). Poljoprivredno zadrugarstvo u Republici Srbiji: Stanje i perspektive. Letopis naučnih radova, 31(1):114-121.

16. McNamara, J. (2007). Co-operative Potential in the Global Arena: Progress Based on Principles. Canadian Association for Studies in Co-operation, University of Saskatchewan, Saskatoon, Canada, retrieved at: http://usaskstudies. coop/socialeconomy/files/congress07/mcnamara.pdf, $16^{\text {th }}$ March 2021.

17. Mihajlović, L., Tomić, D. (1992). Zadrugarstvo u jugoslovenskoj poljoprivredi. Ekonomika poljoprivrede, 9/10:333-341.

18. Milton, J., Klostes, E. (2009). A Popularist View of Cooperative Principles. Agribusiness Management, Washington State University, Pullman, USA.

19. Nikolić, M. (2014). Implementation of cooperative values and principles and their influence on business of agricultural cooperatives in Serbia. Dissertation, Faculty of Agriculture, University of Belgrade, Serbia.

20. Nikolić, M. (2018). Modeli finansiranja zadruga. Finansije, 73(1-6):66-88.

21. Nilsson, J. (1996). Cooperative Principles and Practices in Swedish Agricultural Cooperatives. Co-operatives, Markets, Co-operative Principles, Uppsala, Sweden. 
22. Novkovic, S. (2005). Cooperative business: What is the role of cooperative principles and values? In: XXI ICA Research Conference, 11-14 ${ }^{\text {th }}$ August 2005, Cork, Ireland.

23. Novkovic, S. (2008). Defining the co-operative difference. The Journal of SocioEconomics. 37(2008):2168-2177.

24. Njegovan, Z. (2011). Agrarno ili zadružno pitanje: Prilog za razumevanje zadrugarstva u Republici Srbiji. Ekonomika preduzeća, 59(5-6):297-307.

25. Ranđelović, V. (1994). Zadružni oblici u poljoprivredi Srbije u periodu posle Drugog svetskog rata. In: 100 godina zemljoradničkog zadrugarstva Srbije, Zadružni savez Srbije, Beograd, Srbija, pp. 60-73.

26. Szabó, G. (2009). The importance and role of trust in agricultural producerowned organizations. In: Transition in Agriculture: Agricultural Economics in Transition VI, Institute of Economics, Hungarian Academy of Sciences, Budapest, Hungary, pp. 1-22.

27. Zakić, V., Nikolić, M. (2018). Finansijska podrška države zadrugama u Srbiji. Škola biznisa, 2018(1):158-174, doi: 10.5937/skolbiz1-19686.

28. Zakić, Z. (2000). Koopmenadžment. Dunav grupa, Beograd, Srbija.

29. Zeuli, K., Radel, J. (2005). Cooperatives as a Community Development Strategy: Linking Theory and Practice. Journal Regional Analisys and Policy, 35(1):43-54. 